\title{
STUDIES OF LINKAGE IN POPULATIONS
}

\section{AN ASSOCIATION OF LINKED INVERSIONS IN DROSOPHILA GUARAMUNU}

\author{
M. LEVITAN and F. M. SALZANO
}

Woman's Medical College of Pennsylvania, Philadelphia, and Instituto de Ciências Naturais Universidade do Rio Grande do Sul, Pôrto Alegre, Brazil

Received 10.vii. $5^{8}$

ONE of us (Levitan I954a, I954b, I955, I957, I958b) has recently found that linked gene arrangements of $D$. robusta exist in non-random associations in two woods near Blacksburg, Virginia. Conclusive demonstration of the associations involved laborious crosses of wildcaught adults to laboratory strains. Using a basically similar method to analyse several wild strains Brncic (I953) noted that two widespread "independent" inversions $E$ and $H$ on the fourth chromosome of Drosophila guaramunu are "almost always associated in the same chromosome". In the data of da Cunha, Brncic and Salzano (r953) and Salzano (I955) studying populations of $D$. guaramunu from several Brazilian localities these two arrangements were heterozygous with almost identical frequencies in each place. The present paper, using the raw data of Salzano (I955), and some unpublished data of that author, will show that the association of these inversions is a most remarkable one which can be conclusively demonstrated even in larval (" egg sample") data.

Materials and methods, localities studied, etc., are given in the cited papers of Brncic, da Cunha et al., and Salzano. Briefly, the data by Salzano discussed here were derived from study of the salivary chromosome of one female larva from each inseminated wild-caught female (so-called "egg" samples). For the $H$ inversion the results were recorded as to heterozygosity $(H h)$ or homozygosity for arrangemexit, the two types of homozygotes, $H H$ and $h$, not being distinguishable; for $E$, however, all three karyotypes, $E E, E e$ and $e e$ were distinguished for all collections after September 1952. The few data of Salzano obtained prior to September $195^{2}$ will be ignored.

Both $E$ and $H$ are simple (two break) paracentric inversions with respect to Standard (Brncic, 1953). Both are moderate in size, $E$ extending about half again the length of $H$. The euchromatin in the uninverted section between them, very nicely shown in fig. 3 of Brncic (I953), consists of at least thirty eight bands, about fifty if double bands are counted as two bands each. (A comparison of the figure cited with Brncic's map of the salivary chromosome indicates that, contrary to the text, the distance between the inversions includes sections 70, 7I, and 72; this interpretation has been confirmed by the observations of these inversions by the junior author.) 
The data for the four localities where all $E$ karyotypes were detcrmined are shown in tablc $\mathrm{r}$. Not a single instance of ee with $H$ h was recorded in the II 5 larva examined. Since ee were rare in most of the collections this might be attributable to chance, but such is

\section{TABLE I}

Egg sample karyotypes at the $\mathrm{E}$ and $\mathrm{H}$ inversion loci on chromosome-4 of D. guaramunu from four Brazilian localities

\begin{tabular}{|c|c|c|c|c|c|c|c|c|}
\hline $\begin{array}{l}\text { Locality } \\
\text { and date }\end{array}$ & $\mathcal{N}$ & $\begin{array}{c}E E \\
\& H h\end{array}$ & $\begin{array}{c}E \& \\
\& H h\end{array}$ & $\stackrel{e e}{\& I h}$ & $\begin{array}{l}\text { All } \\
E E\end{array}$ & $\begin{array}{l}\text { All } \\
E e\end{array}$ & $\begin{array}{c}\text { All } \\
e e\end{array}$ & $\begin{array}{l}E e \text { with } \\
H H \text { or } h h\end{array}$ \\
\hline $\begin{array}{l}\text { Bcxiga } \\
\text { Feb. '53 } \\
\text { May '53 } \\
\text { Aug. '53 } \\
\text { Nov. '53 }\end{array}$ & $\begin{array}{l}100 \\
100 \\
100 \\
100\end{array}$ & $\begin{array}{l}0 \\
0 \\
2 \\
4\end{array}$ & $\begin{array}{l}43 \\
39 \\
40 \\
16\end{array}$ & $\begin{array}{l}0 \\
0 \\
0 \\
0\end{array}$ & $\begin{array}{l}40 \\
24 \\
17 \\
82\end{array}$ & $\begin{array}{l}43 \\
39 \\
40 \\
16\end{array}$ & $\begin{array}{r}17 \\
37 \\
43 \\
2\end{array}$ & $\begin{array}{l}0 \\
0 \\
0 \\
0\end{array}$ \\
\hline All Bexiga & 400 & 6 & $13^{8}$ & o & I 63 & ${ }^{1} 3^{8}$ & 99 & 0 \\
\hline $\begin{array}{l}\text { Emboaba } \\
\text { Jan. '5.3 } \\
\text { July '53 } \\
\text { Oct. '53 }\end{array}$ & $\begin{array}{r}88 \\
\text { I } 4 \\
\text { 1 } 00\end{array}$ & $\begin{array}{l}\text { I } \\
0 \\
2\end{array}$ & $\begin{array}{r}9 \\
1 \\
16\end{array}$ & $\begin{array}{l}0 \\
0 \\
0\end{array}$ & $\begin{array}{r}68 \\
2 \\
76\end{array}$ & $\begin{array}{r}9 \\
I \\
I 6\end{array}$ & $\begin{array}{r}\text { I I } \\
\text { I I } \\
8\end{array}$ & $\begin{array}{l}0 \\
0 \\
0\end{array}$ \\
\hline All Emboaba & 202 & 3 & 26 & 0 & I 46 & 26 & $3^{\circ}$ & 0 \\
\hline $\begin{array}{l}\text { Feliz } \\
\text { Dec. '52 } \\
\text { Fcb. '53 } \\
\text { June '53 } \\
\text { Aug.-Sept. '53 } \\
\text { Dec. '53 }\end{array}$ & $\begin{array}{r}100 \\
100 \\
100 \\
80 \\
100\end{array}$ & $\begin{array}{l}\mathrm{I} \\
\mathrm{I} \\
3 \\
0 \\
6\end{array}$ & $\begin{array}{l}20 \\
17 \\
22 \\
14 \\
24\end{array}$ & $\begin{array}{l}0 \\
0 \\
0 \\
0 \\
0\end{array}$ & $\begin{array}{l}78 \\
83 \\
73 \\
61 \\
67\end{array}$ & $\begin{array}{l}20 \\
17 \\
22 \\
14 \\
24\end{array}$ & $\begin{array}{l}2 \\
0 \\
5 \\
5 \\
9\end{array}$ & $\begin{array}{l}0 \\
0 \\
0 \\
0 \\
0\end{array}$ \\
\hline All Feliz & 480 & II & 97 & o & $3^{62}$ & 97 & $2 \mathrm{I}$ & o \\
\hline $\begin{array}{l}\text { Ponta Grossa } \\
\text { Oct. '52 } \\
\text { July-Aug. '53 }\end{array}$ & $\begin{array}{l}\text { I9 } \\
50\end{array}$ & $\begin{array}{l}0 \\
0\end{array}$ & $\begin{array}{r}5 \\
16\end{array}$ & $\begin{array}{l}0 \\
0\end{array}$ & $\begin{array}{l}2 \\
2\end{array}$ & $\begin{array}{r}5 \\
16\end{array}$ & $\begin{array}{l}12 \\
32\end{array}$ & $\begin{array}{l}0 \\
0\end{array}$ \\
\hline All Ponta Grossa & 69 & ( & $2 !$ & o & 4 & $2 \mathrm{I}$ & 41 & o \\
\hline
\end{tabular}

certainly not the case at Ponta Grossa and in three of the four Bexiga collcctions. At Feliz, furthcrmore, the deficiency of $e e$ with $H h$ is significant in the total sample: ee being 4.4 per cent. (2I/480) of the total, one would cxpect by chance 4.4 per cent., or $4 \cdot 8$, of the I $88 \mathrm{Hh}$ individuals to be $e e$; the deviation from expected has $\chi^{2}$ of $5^{\circ} \mathrm{o}$ for one d.f. ( $\mathrm{P}$ about $\cdot 02.5$ ) without Yates' corrcction, $\chi^{2}$ of $4^{\circ} \mathrm{O}$ $(\mathrm{P}-05)$ with Yates' correction. Likewise at Emboaba, $\chi^{2}$ is $4 \cdot 8$ ( $\mathrm{P}$ about $\cdot 04$ ) without Yates' corrcction, $3 \cdot 7$ ( $\mathrm{P}$ about $\cdot 06$ ) with Yates' correction. For a composite of all samples with few ee or few $H h$ (the Spring Bcxiga and all the Emboaba and Feliz data), the deficiency of ee with $H h$ from cxpected $(17 \cdot 4)$ is highly significant (as it is in the thrce Bexiga and the Ponta Grossa samples where ee was common). 
$H h$ larvæ of karyotype $E E$ do occur at all three localities, but these also are rarer than expected. The deficiences are highly significant in every large sample $(\mathcal{N} \geqq 80)$ except the winter Bexiga one (where $\chi^{2}$ is $4 \cdot 46$ with $\mathrm{P}$ about $\cdot 04$, i.e. barely significant).

Turning to the $E e$ larvæ, one can determine how often they were found with an homozygous " $H$ " karyotype $(H H$ or $h h)$ by subtracting the total number of $E e$ (column 5) from the number of " $E e$ with $H h$ " (column 2). The results are shown in the extreme right-hand column. Out of II5I larvæ not a single instance of $E e$ that was not also $H h$ was found. The deficiency of " $E e$ with $H H$ or $h h$ " from the number expected by chance (based on the number of $H h$ and $h h$ present) is highly significant in every sample of fifty or more larvæ, even the summer Emboaba one with only nine $E e$.

To sum up, of the II 5 I larvæ recorded for the linked inversions $E$ and $H$, only 20 ( $\mathrm{I} \cdot 7$ per cent.) were heterozygous for one arrangement and homozygous for another (EEHh, eeHh, EeHH, Eehh), the other I I3 I (98.3 per cent.) being either doubly homozygous ( $E E H H, E E h h$, $e e H H$, and $e e h h)$ or doubly heterozygous $(E e H h)$. The double homozygotes total 849 ( 73.8 per cent.), the double heterozygotes $282(24.5$ per cent.). No imaginable karyotype frequencies at the two inversion loci could produce such a distribution of zygotic combinations by chance. Clearly a non-random association has been demonstrated here despite the handicaps that only larval (" egg sample") data are available and not all karyotypes could be distinguished at one of the loci.

Two explanations of these data seem possible, one at the chromosome or " gametic" level, the other at the zygotic level. At the gametic level, assume one of the linkages to be most primitive, say $E H$. Inversion of, say, the " $E$ " segment produced $e H$ chromosomes, then inversion of the " $H$ " segment on either $E H$ or $e H$ produced, say, $E h$ (assuming the inversion occurs on $E H$ ). Confining our attention to the larger samples at Bexiga, Emboaba and Feliz, it may be noted that $E E$ has a minimum frequency of I7 per cent., and occurs almost exclusively with homozygotes for the " $H$ " locus (in linkage notation, $E H / E H$ or $E h / E h)$; this means that in these populations either $E H$ or $E h$, but not both, must be common. If both were common, $E E$ with $H h(E H / E h)$ would not be such a deficient combination; and if both were rare, homozygous $E E$ would be rare, the frequency of $E E$ being at least the square of the frequency of $E$ in each sample. (Note that even where highly significant deviations from the Hardy-Weinberg Law occur, in the two large Emboaba and the summer Feliz samples, they involve an excess of EE.) Crossing-over in $E h / e H$ females would produce some $e h$ chromosomes. Whether these have become common or remained rare depends on which of the $E$ linkages, $E H$ or $E h$, became the common one. If $E h$ became common, then $e h$ must have remained rare, otherwise Eehh (Eh/eh in linkage form) would be more frequent; $e H$, on the other hand, would then need to have attained $\mathrm{Q}^{2}$ 
a fairly high frequency, for frequent $E h$ means that the common double heterozygotes ( $E e$ with $H h$ ) are almost exclusively of linkage type $E h / e H$. The argument would be reversed if $E H$ became the common " $E$ " linkage : $e H$ must then have remained rare (hence the rarity of $E H / e h$ ) and $e h$ common (to account for the frequency of " $E e$ with $H h$ ", which are almost exclusively $E H / e h$ when $e H$ and $E h$ are rare). In any case, it can be scen that either the two coupling or cis linkages ( $E H$ and $e h$ ) must be common, the two repulsion (trans) linkages $(E h$ and $e H)$ rare, or vice versa, to account for the data.

Brncic (1953) has suggested that the probable phylogeny in these populations is (re-written here in linkage form) :

$$
e h \longleftrightarrow E h \longleftrightarrow E H,
$$

the two end members being the most common in these populations. On this scheme linkage $e H$, if it exists, would have arisen by crossingover. As Brncic points out, other possible schemes, albeit less probable, are consistent with the data, as, for cxample:

or,

$$
\mathrm{eh} \longleftrightarrow \mathrm{eH} \longleftrightarrow \mathrm{EH} \longleftrightarrow \mathrm{Eh}
$$

$$
\mathrm{Eh} \longleftrightarrow \mathrm{eh} \longleftrightarrow \mathrm{eH} \longleftrightarrow \mathrm{EH},
$$

in each of which either of the end members arose by crossing-over. These alternative schemes assume $e H$ is a comparatively old arrangement which has proven adaptively weak in these populations. The final conclusion in the previous paragraph is valid, however, no matter what the phylogeny (or notation) of the arrangements is. It should also be noted that on any scheme one of the two common linkages must have become more frequent, via natural selection, than at least one linkage of carlier origin. For example, if $E H$ and $e h$ are now the most common combinations, of which $E H$, say, is the more primitive, eh has become more common than $E h$ and $e H$, at least one of which antedate it.

D. robusta also has an association characterised by excess of the two coupling linkages and deficiency of the two repulsion linkages. (Levitan, 1954b, 1957 and 1958b). The deviations from randomness are small, albeit significant, and were not suspected from the egg sample data. The $X L-2$. XR-2 association of $D$. robusta (Carson and Stalker, I949; Carson, I958; Levitan, I958a,b), on the other hand, does resemble this one in that it may be inferred, though not as conclusively, from egg sample data. The probable phylogeny is:

$$
X L . X R \longleftrightarrow X L . X R-2 \longleftrightarrow X L-2, X R-2
$$

The combination $X L-2 . X R$ (analogous to eH here), probably produced by crossing over, is extremely rare or absent in natural populations. Unlike the $D$. guaramunu association, the two most common linkages are probably the oldest, one a "coupling", the other a "repulsion" linkage, but $X L-2, X R-2$ is more frequent than at least 
one of its two probable predecessors in two recorded samples of more than 20 chromosomes (samples 16 and 18 in table 4 of Carson, I958) and in several smaller ones (op. cit.). Both the D. guaramunu and $D$. robusta associations demonstrate, then, instances when a phylogenetically more recent linkage combination has increased in frequency by natural selection, its greater adaptive value overcoming the tendency of crossing-over to break it down.

This conclusion seems warranted even though the cxistence of linkage $e H$ in these populations is uncertain. It may be argued that inasmuch as the space between inversions $E$ and $H$ is small (presumably Io-I5 per cent. of the euchromatin of chromosome-4), possibly crossing-over between the two has never occurred. This seems highly unlikely, however, since crossing-over in even smaller regions have been recorded, for example, in the well-known distal end of the $\mathrm{X}$-chromosome of $D$. melanogaster, not to speak of the crossing-over in pseudo-alleles. Wasserman and Wilson (1957) report the existence of all four combinations of independent inversions $2 s^{2}$ and $2 y^{2}$ and their Standard counterparts in a Mexican species of the repleta group, D. nigricruria, indicating that crossing-over has occurred at least once in the uninverted region between the inversions. According to Wasserman and Wilson (op. cit.) this region, between sections $\mathrm{E}_{3 \mathrm{C}}$ and E4a of chromosome-2, contains " approximately ten bands"; judging from the D. repleta map of Wharton (1942), one would assume their statement includes light- as well as dark-staining bands. In any case, the region is considerably smaller than the one between $E$ and $H$ of D. guaramunu.

An alternative hypothesis is that the non-random condition of the linkages is a by-product of competition at the zygotic lcvel, the double homozygote with, say, coupling combinations being adaptively superior to the homozygotes for the reverse (repulsion) combinations and to the individuals homozygous for one arrangement, heterozygous for the other. The double heterozygotes would be almost exclusively of the same nature as the dominant homozygotes (opposite coupling linkages in the example). This seems a more difficult system to evolve than the one envisaged by the gametic level hypothesis, but our data do not enable us to distinguish between the two hypotheses. A re-study of the populations distinguishing between the homozygotes $H H$ and hh may determine which is correct. The most significant point is that under either hypothesis some adaptive interaction between independent inversions must be postulated to explain the non-random association.

\section{SUMMARY}

Drosophila populations in four Brazilian localities contain an extreme non-random association of two "independent" inversions of the fourth chromosome. Individuals homozygous for one arrangement and heterozygous for the other are very rare in the populations, 
over 98 per cent. of the egg sample larvæ being either heterozygous for both inversions or homozygous at both inversion loci.

The results are probably attributable to differential selection for chromosomes with ccrtain combinations of the arrangements, the two coupling (cis) combinations probably bcing favourcd, the two repulsion (trans) combinations selected against.

Acknowledgments.- The authors are grateful to the Conselho Nacional de Pesquisas. of Brazil and the Rockefeller Foundation for support during the collection of the data in this specics by onc of us (F. M. S.) and to the National Science Foundation for equipment used by M. L. during preparation of the manuscript.

\section{REFERENCES}

BRNCIC, D. J. I953. Chromosomal variation in natural populations of Drosophila guaramınu. Z.I.A.V., 85, I-I I.

Carson, H. L. i958. The population genetics of Drosophila robusta. Adr. in Genetics, 9, I-40.

CARSON, II. L., AND STAI.KeR, H. D. I949. Seasonal variation in gene arrangement frequencics over a three-year pcriod in Drosophila robusta Sturtevant. Evolution, $3,322-329$.

D. CUNIIA, A. B., BRNGIG, D., AND SAlzano, F. M. I953. A comparative study of chromosomal polymorphism in ccrtain South American species of Drosophila. Heredity, 7, 193-202.

Levitan, M. 19.54a. Position effects in natural populations. Amer. Nat., 88, 419-423. LEVITAN, M. I 95.4 . Additional evidence of position effects in natural populations. Genetics, 39, 979 .

revitan, м. 195.5. Studies of linkage in populations. I. Associations of second chromosome inversions in Drosophila robusta. Evolution, 9, 62-74.

Levitan, M. 1957. Natural selection for linked gene arrangements. Anat. Rec., 127,430 .

LEVITAN, M. I958a. Studies of linkage in populations. II. Recombination between inversions in Drosophila robusta. Genetics, 43, 620-633.

LEvitan, M. 1958b. Non-random associations of inversions. C.S.H. Symp. on Quant. Biol., 23, 25 I-268.

SAlzano, F. M. I955. Chromosomal polymorphism in two species of the guarari group of Drosophila. Chromosoma, 7, 39-50.

WASSERMAN, M., ANI WILSON, F. D. I957. Further studies on the repleta group. Univ. Texas Publ., $5721,132-156$.

Mindrton, i. т. 1942. Analysis of the repleta group of Drosothila. Univ. Texas Publ., 4228, 23-52. 